Estetologia Medyczna i Kosmetologia, 2012, Tom 2, Suplement 1, s1-s14 DOI: http://dx.doi.org/10.14320/EMK.2012.026

\title{
estetologia med y $\underset{z}{ } \mathrm{n}$ a kosmetólogia
}

„Od Estetyki do Zdrowia”

Krakowska Akademia im. A. Frycza Modrzewskiego

Kraków, 16-18 marca 2012

Materiały z konferencji

Redaktor suplementu:

Zbigniew Rybak

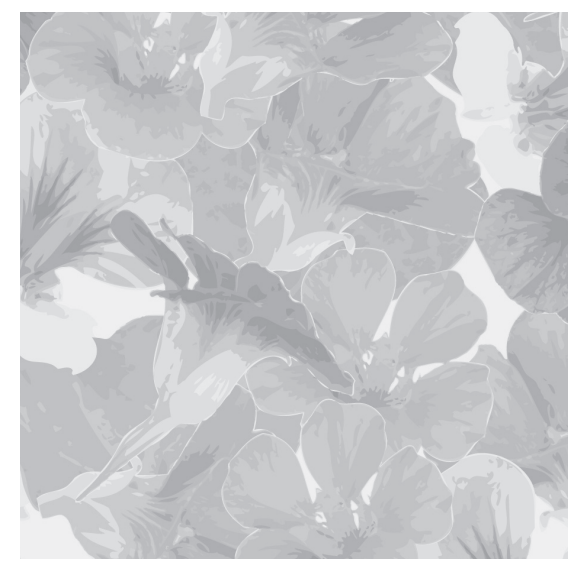




\title{
Andropauza: fakty i mity
}

\author{
Zygmunt Zdrojewicz
}

\section{Klinika Endokrynologii, Diabetologii i Leczenia Izotopami AM we Wrocławiu}

Według Polskiego Towarzystwa Menopauzy i Andropauzy, andropauza to okres życia mężczyzny po pojawieniu się postępujących wraz z wiekiem niedoborów hormonów androgenowych, testosteronu i dehydroepiandrosteronu, a także hormonów wzrostu i melatoniny, które to zjawiska rozwijają się zwykle po 50 r.ż. Symptomatologia tych zmian charakteryzuje się stopniowym pogarszaniem się jakości życia, ogólnego samopoczucia, sprawności w pracy, zaburzeniami libido i funkcji seksualnych, zmniejszeniem sprawności intelektualnej i zaburzeniami snu. Celem wykładu jest przedstawienie patofizjologii tego okresu z uwzględnieniem diagnostyki klinicznej, laboratoryjnej, terapii, a także omówienie mitów związanych z andropauzą. W podsumowaniu należy stwierdzić, że mężczyźni „w jesieni życia” wymagają szczególnej opieki lekarskiej. Osiągnięcia medycyny sprawiają jednak, że przy pomocy lekarza rodzinnego, urologa, endokrynologa, seksuologa starzenie się - chociaż niestety nieuniknione - może przebiegać w sposób łagodny, nie pogarszający znacząco jakości życia, czyli „miło, łatwo i przyjemnie”.

\section{Atrakcyjność czyli sygnał o zdrowiu i płodności wpisany w kod genetyczny}

\section{Maria Kapiszewska}

\section{Krakowska Akademia im. Andrzeja Frycza Modrzewskiego, Wydział Zdrowia i Nauk Medycznych, Kraków}

Zdolność adaptacyjna do szybko zmieniającego się środowiska jest najważniejszą cechą osobniczą. W jej osiągnięciu pomaga zróżnicowanie genetyczne, chroniące jednocześnie populację przed wyniszczeniem przez atak patogenów czy pasożytów, które nie tylko się rozmnażają szybciej, ale także szybko się rozprzestrzeniają. Zróżnicowanie to zawdzięczamy rekombinacjom genetycznym zachodzącym w trakcie zapłodnienia w rozmnażaniu płciowym. Jakość materiału genetycznego obydwu partnerów jest podstawą sukcesu kolejnych pokoleń. Miarą tego sukcesu jest nie tylko zdolność do przeżycia ale także, a może przede wszystkim, przekazanie swoich genów jak największej liczbie potomstwa. Jak zatem rozpoznać, który z potencjalnych partnerów ma najlepszy zestaw genów? Śledzenie ewolucyjnych zmian wyraźnie wskazuje, że u podstaw selekcji płciowej leży fizyczna atrakcyjność, a ona z kolei jest odzwierciedleniem fenotypowej jakości idącej w parze z „dobrymi genami”. Cechy adaptacyjne zapewniające najlepsze przystosowanie, a tym samym przeżycie, niestety nie zawsze idą w parze z odpowiedzialnymi za sukces reprodukcyjny „genami atrakcyjności”. Oznaki zewnętrznej atrakcyjności wydają się być ważniejsze, bowiem seksowność i atrakcyjność zapewniają przedłużenie gatunku, decydują o sukcesie w znalezieniu partnera i są oznaką najlepszego zestawu genów. Ryzyko w wyborze niewłaściwego partnera jest nie tylko zbyt kosztowne, zwłaszcza dla samic (kobiet), które ponoszą znacznie większe energetyczne koszty reprodukcji, ale także stanowi zagrożenie dla potomstwa. W ramach teorii doboru płciowego ścierają się dwie koncepcje: tzw. wersja „dobrych genów” (zdrowe potomstwo i rozsądek, czyli kryteria praktyczne) i wersja Fishera („dobry smak”, poczucie piękna). Czyli kryterium w wyborze partnera może należeć do cech użytecznych lub być czysto estetyczne. Piękno jako oznaka genetycznych przymiotów, na przykład odporności czy siły fizycznej, zapewni potomstwu łatwiejsze znalezienie partnera. Obydwie wersje doboru opisują jedynie sposób selekcji „najlepszych” samców, bo zgodnie z dotychczasową wiedzą to samice dokonują wyboru. Nawet jeśli wybór jest nieświadomy - czysto instynktowny, to u jego podstaw często leży moda. Despotyzm mody i zniewolenie jej nakazami jest zjawiskiem znanym także w świecie zwierząt. Wybór jest często pozorny, jest bowiem w istocie raczej naśladowaniem innych. Pożądany przez inne osobniki żeńskie samiec oznacza największe prawdopodobieństwo sukcesu reprodukcyjnego, a to rokuje największe szanse na kolejny sukces reprodukcyjny jego męskich potomków. Modele matematyczne wspierają tą wersję doboru partnera. Nauka rozpatruje wiele cech, które mierzą ,genetyczne piękno” czyli takich, za którymi kryją się „dobre geny”. Należy do nich symetria - organizmy powstające 
w dobrych warunkach wykazują tę właśnie cechę. Wszelkie zaburzenia środowiskowe, zanieczyszczenia, stres odzwierciedlają się w asymetrii ciała. Symetria urody zapewnia łatwe znalezienie partnera, a to już połowa sukcesu reprodukcyjnego. Godną pożądania cechą wyglądu zewnętrznego jest także kształt sylwetki, będący równocześnie przesłaniem o zdrowiu i płodności. Kobieca sylwetka typu „klepsydra” (stosunek tali do bioder około 0,7 a nie bezwzględne wymiary), BMI, symetria twarzy i wiele innych cech to matematyka ludzkiej seksualności, ale także predykatory zdrowia. Wybór partnera musi je uwzględniać, aby nasze „,samolubne" geny odniosły sukces i pozostały w puli kart, którą gra ewolucja. Żadna jednak, nawet najbardziej wyrafinowana teoria doboru płciowego nie potrafiła do tej pory rozwikłać wielu paradoksów w wyborze partnera.

\title{
Zakrzepica żylna i tętnicza - problem wieku dojrzałego
}

\author{
Tomasz Urbanek \\ Katedra i Klinika Chirurgii Ogólnej i Naczyń, Śląski Uniwersytet Medyczny w Katowicach
}

Mimo coraz większej świadomości społecznej dotyczącej powikłań zakrzepowych w układzie żylnym jak i tętniczym, problem ten wydaje się ciągle być niedoceniany zarówno przez pacjentów jak i personel medyczny. Szacunkowe dane oparte na ekstrapolacji wyników badań autopsyjnych sugerują, że rocznie na terenie Unii Europejskiej na skutek powikłań żylnej choroby zakrzepowo zatorowej umiera ponad 500000 osób. Problem powikłań zakrzepowych w układzie tętniczym wydaje się być jeszcze bardziej istotny, stawiając choroby serca i naczyń na pierwszym miejscu wśród przyczyn zgonów w naszym społeczeństwie. Na tle powyższych informacji szczególnego znaczenia nabiera problem właściwej profilaktyki przeciwzakrzepowej odnoszącej się zarówno do ryzyka żylnej choroby zakrzepowo-zatorowej jak i zakrzepicy tętniczej. Wykład przedstawia aktualne informacje dotyczące czynników ryzyka żylnej choroby zakrzepowo-zatorowej zarówno u pacjentów leczonych zabiegowo, jak i w grupie „medical patients”. Zwrócono również uwagę na sytuacje kliniczne, z którymi spotykamy się wszyscy w życiu codziennym, takie jak unieruchomienie związane z podróżą, tryb życia czy też uprawianie sportu - czynniki rzadko kojarzone z ryzykiem powikłań zakrzepowych. W oparciu o aktualne wytyczne przedstawiono obowiązujące zasady profilaktyki przeciwzakrzepowej z uwzględnieniem zarówno pacjentów poddawanych leczeniu zabiegowemu, jak i leczonych zachowawczo. Szczególną uwage zwrócono na epidemiologię chorób serca i naczyń w Polsce oraz ich wpływ na oczekiwaną długość trwania życia oraz ryzyko powikłań sercowo naczyniowych. Omawiając problem zakrzepicy tętniczej przedstawiono najczęstsze i najistotniejsze zagrożenia wpływające na ryzyko zgonu z przyczyn naczyniowych. Jednocześnie zaproponowano oparty o aktualne wytyczne sposób postępowania profilaktycznego mającego na celu zmniejszenie powikłań sercowo-naczyniowych.

\section{Pacjent na przełomie szóstej i siódmej dekady życia - perspektywa lekarza rodzinnego}

\author{
Adam Windak \\ Zakład Medycyny Rodzinnej, Katedra Chorób Wewnętrznych i Gerontologii, \\ Collegium Medicum UJ w Krakowie
}

Przełom szóstej i siódmej dekady życia to okres wielowymiarowych zmian mających istotny wpływ na zdrowie człowieka. Rosnąca z wiekiem zapadalność i chorobowość licznych schorzeń przewlekłych warunkuje w dużym stopniu stan zdrowia fizycznego. W obszarze zdrowia psychicznego największego znaczenia nabiera depresja, a w wymiarze społecznym na pierwszy plan wysuwa się wygaszanie aktywności zawodowych, zmiana funkcji społecznych, a nierzadko też statusu materialnego. Elementy te determinują jakość życia, także w perspektywie zbliżającej się starości w dużym stopniu zależąc od wpływów środowiskowych, w tym modyfikowalnych zachowań zdrowotnych i czynników ryzyka. Możliwość skutecznego oddziaływania na nie stanowi wyzwanie dla każdego lekarza rodzinnego. 


\title{
Orthopedic complications of diabetes mellitus
}

\author{
Maxim Gurevich \\ Hillel Yaffe Medical Center, Israel
}

Type 2 Diabetes is now a pandemic and shows no signs of abatement. The estimated worldwide prevalence of diabetes among adults was 285 million (6.4\%) in 2010 and this value is predicted to rise to around 439 million (7.7\%) by 2030 . Type 2 diabetes is the predominant form and accounts for at least $90 \%$ of cases. The rise in prevalence is predicted to be much greater in developing than in developed countries (69\% vs. 20\%). The excess global mortality in 2000 attributable to diabetes overall (most of them diabetes 2) was 2.9 million $(5.2 \%)$ deaths. In 2004, heart disease and stroke were reported on $68 \%$ and $16 \%$, respectively, of diabetes related death certificates in the USA. Furthermore, diabetes is leading cause of blindness among adults aged $20-74$ years, and leads to around $44 \%$ of end-stage renal failure and $60 \%$ of non-traumatic lower limbs amputations in the USA.

Diabetic foot (DF) is a major cause of morbidity and mortality for diabetes patient and consumes a great deal of health system resources. Foot problems represent $20 \%$ of total reasons for hospital admission of diabetes patients. DF amputations account of $2 / 3$ of all non-traumatic amputation in all developed countries. Diabetic patient can present wide range of orthopedic problems: neuropathy without infection, macroangiopathy, infectious pathology, neuroarthropathy, tendons ruptures, foot deformities, complications associated with regular orthopedic surgeries (poor operation wounds healing, etc.). Three major mechanisms stand in the base of orthopedic complications of diabetes: neuropathy, vasculopathy, and abnormal mechanical environment. Protective sensation plays the most important role in preventing development of diabetic ulcer. Besides sensory neuropathy there are also other kinds of neuropathies in diabetes patient: diabetic amyotrophy, diabetic mononeuropathy, motor neuropathy, autonomic neuropathy. Abnormal mechanical environment together with neuropathy and vasculopathy gives rise to diabetic ulcers.

Prevention and early detection of diabetic ulcer helps to save affected limb from deterioration and amputation. There are couples of classification systems for diabetic ulcers (Wagner, Brodsky, and San Antonio). Key points are perfusion, extent (size) of lesion, amount of tissue loss, infection and presence (absence) of sensation. Charcot arthropathy is the special kind of diabetic pathology. Presenting at the diabetic patient, untreated Charcot arthropathy leads to severe deformation of limb, causing non-plantigrade unbootable foot, affected with non healing diabetic ulcer. In most cases the common pathway of untreated Charcot is limb amputation. Good education of patients, early recognition of problems and appropriate treatment include multi-specialist team involvement allow to save the affected limb and patient's life.

\section{Cutting edge techniques for intensive skin regeneration}

\author{
Volodymyr A. Tsepkolenko
}

\section{Aesthetic Medicine Institute Virtus, Odessa, Ukraine}

One of the priority areas of modern aesthetic medicine (AM) development is finding and starting practical application of new methods and techniques aimed at intensifying skin regenerative processes. Development of application algorithm of using cutting edge techniques for intensive skin regeneration is considered to be an important landmark of AM progress. The scheme is designed to increase moisture content in dermal matrix, adequate skin stimulation based on its physiological capabilities, aiming to reconstruct its 3-dimensional organization, qualitative and quantitative parameters of fibrous structure, as well as to increase proliferative activity of fibroblasts. The scheme includes 4 important components (each of which has its own indications): Redermalization (use of combined medication containing hyaluronic acid and sodium salt of succinic acid); application of autologous plasma rich in growths factors; application of human placenta products; fractional photothermolysis. We have studied the effectiveness of the combined approach that consists of the above 
mentioned components, from the perspective of evidence-based medicine. The study group included 108 patients between 41 and 71 years of age with involutional-dystrophic skin changes. Ultrasound examination of all patients demonstrated improvement of such objective indices, as greasiness, hydration, electro-conductivity and density as assessed by sonography. Combined approach is highly efficient, and available for most AM doctors as a convenient technique for intensive skin regeneration, without causing any side effects when properly executed.

\title{
Czynniki osobnicze i środowiskowe wpływające na stan skóry i profilaktykę przeciwstarzeniową
}

\author{
Monika Kapińska-Mrowiecka \\ Oddział Dermatologii i Alergologii Szpitala Wojewódzkiego w Krakowie
}

Kondycja skóry, największego narządu człowieka zależy od bardzo wielu czynników. Czynniki genetyczne determinują typ skóry, np. skóra sucha i atopowa zależy od mutacji genu filagryny, zaburzeń funkcji naskórka jako bariery z tendencją do nadmiernej utraty wody. Ten typ skóry łatwo podlega niekorzystnym wpływom dietetycznym, klimatycznym i środowiskowym, łatwo dochodzi także do podrażnienia miejscowego wywołanego środkami i zabiegami pielęgnacyjnymi oraz kosmetykami. Skóra łojotokowa i trądzikowa stanowi obecnie duży problem estetyczny, także u osób dorosłych Podłoże genetyczne i rodzinne odgrywa rolę determinującą odpowiedź na czynniki środowiskowe. Wśród wielu rozważanych czynników patogenezy zmian skórnych uwzględniane są oporne szczepy bakterii, doustna antykoncepcja, nieprawidłowa dieta, źle dobrane kosmetyki i nieprawidłowa pielęgnacja skóry. Wśród czynników wpływających niekorzystnie na stan skóry łojotokowej najczęściej podkreśla się udział zaburzeń hormonalnych jako kluczowych w patogenezie, ponadto wskazuje się na rolę stresu, palenia tytoniu, leków i ekspozycji na promienie słoneczne (solarium).

Czynniki środowiskowe, takie jak przebywanie w klimatyzowanych pomieszczeniach, sposób odżywiania, korzystanie z naturalnych zabiegów pielęgnacyjnych (SPA) i ekspozycja na czynniki klimatyczne są aktualnie szczegółowo analizowane jako ważne uwarunkowania profilaktyki przeciwstarzeniowej. Starzenie fizjologiczne (intrinsic aging) jest procesem złożonym, wynikającym z kodu genetycznego, cechującym się zmniejszeniem rezerw komórkowych tkanek oraz pogorszeniem zdolności komórek do pełnienia swych fizjologicznych funkcji. Jednym z pierwszych objawów starzenia się skóry jest jej suchość, spowodowana utratą zdolności do wiązania wody i zatrzymywania jej w naskórku. Podobnie wygląda sytuacja w skórze właściwej - nawet minimalny niedobór wody powoduje zmiany w strukturze przestrzennej kolagenu i elastyny oraz utratę elastyczności i sprężystości włókien. Efektem tego procesu jest powstawanie na skórze zmarszczek. Przedłużające się przesuszenie może doprowadzić do trwałej utraty sprężystości i jest uznawane za jeden z czynników przyspieszających starzenie się skóry. Do tego procesu dochodzi również w wyniku działania zewnętrznych czynników środowiskowych, zwłaszcza promieniowania UV i dymu tytoniowego. Objawy starzenia się skóry często jednak nie wiążą się z wiekiem i są cechą indywidualną każdego człowieka. Jakkolwiek starzenie wewnątrzpochodne skóry jest procesem nieuchronnym, stale postępującym i dotyczącym wszystkich warstw skóry, na który mamy niewielki wpływ to jednak można stosować działania profilaktyczne. Chociaż nie mamy wpływu na czynniki genetyczne decydujące o tempie starzenia skóry, to jednak możemy w pewnym stopniu wpływać na czynniki zewnętrzne i zapobiegać pogłębianiu się oznak starzenia skóry. Coraz bardziej zaawansowany wiek, zmniejszone działanie hormonów, palenie papierosów, dieta bogata w węglowodany, ograniczona podaż wody, nadmierne wystawianie na działanie promieni słonecznych, zimna oraz wiatru - wszystkie te czynniki przyczyniają się do rozwoju cech starzenia skóry. Profilaktyka starzenia zewnątrzpochodnego jest łatwiej osiągalna, wymaga jednak znajomości sposobów zapobiegania wpływom środowiskowym i kompleksowego działania z pomocą lekarzy specjalistów. 


\title{
Marginalizacja seksualności osób otyłych w kontekście społecznym
}

\author{
Marta Kowalewska, Anna Goździalska, Jerzy Jaśkiewicz \\ Krakowska Akademia im. A. Frycza Modrzewskiego, Kraków
}

Istotnym wydaje się rozważanie przyczyn marginalizacji seksualności osób otyłych w kontekście społecznym. Filozoficznie można stwierdzić za Tischnerem, że marginalizacja jest „,ucieczką człowieka od człowieka”. Może być zatem rozpatrywana jako zerwanie dialogu z drugim człowiekiem oraz jako dystans fizyczny pomiędzy jednostkami. Jest to zarówno stan rzeczy jak i proces. Wyraża się w tym, że osoba może mieć w istotnym stopniu ograniczone możliwości życiowe, jak i w tym, że ktoś w coraz większym stopniu funkcjonuje poza głównym nurtem życia społecznego. Wykluczenie może przejawiać się w bierności, samotności, alienacji oraz nieprzestrzeganiu społecznie akceptowanych norm współżycia. Skutkami wykluczenia dla osób zagrożonych może być deprywacja potrzeb (w tym także seksualnych), bezradność, osłabienie więzi (partnerskich i rodzinnych) izolacja, osłabienie mechanizmu samokontroli oraz utrata poczucia tożsamości i celu w życiu.

Współczesny dorosły człowiek w tworzeniu własnego obrazu nie może pominąć swojej tożsamości, wyglądu zewnętrznego, sylwetki, sprawności fizycznej i seksualnej. W zadaniach jakie stawia mu środowisko życia, w stylach życia, w uznawanych wartościach „ciało” wyraża odpowiedzialność za własne zdrowie, zachowanie młodości, sprawność. W dużym stopniu odnosi się to do osób otyłych. Otyłość jest chorobą, z którą boryka się coraz większy odsetek populacji współczesnego świata. Dotyczy zarówno kobiet, jak i mężczyzn. Otyłość powoduje negatywne konsekwencje dla różnych aspektów jakości życia, zwłaszcza wśród osób z otyłością olbrzymią. Osoby otyłe mają bowiem wiele fizycznych i psychicznych ograniczeń do pokonania. Dlatego otyłość wiąże się z gorszą jakością życia zależną od zdrowia oraz z gorszym dobrostanem psychicznym. Psychiczna potrzeba kontaktów seksualnych i fizyczna możliwość ich spełnienia dają natomiast podstawy do budowania poczucia wartości, godności i oceny samego siebie w roli partnera życiowego i seksualnego. Ludzie otyli, w przeważającej mierze na skutek kompleksów, mają zaniżoną samoocenę, a tym samym utrudniony dostęp do inicjowania kontaktów damsko-męskich. Dlatego celem psychologicznego leczenia otyłości jest zarówno wzmacnianie poczucia własnej wartości, kształtowanie siły woli oraz odporności na stres, jak i doskonalenie umiejętności radzenia sobie z negatywnymi emocjami.

\section{Otyłość a zachowania seksualne}

\section{Zygmunt Zdrojewicz}

\section{Klinika Endokrynologii, Diabetologii i Leczenia Izotopami AM we Wrocławiu}

Otyłość to poważny problem ekonomiczny, zdrowotny i psychiczny, który dotyczy nie tylko ludzi dorosłych, ale także dzieci i młodzieży. Jej przyczyn upatruje się w genetyce, w sposobie życia, który uległ znacznym modyfikacjom (wysokokaloryczna dieta, łatwość dostępu do produktów spożywczych, mała aktywność ruchowa). Otyłość nie tylko powoduje zwiększenie ryzyka wystąpienia chorób takich jak: cukrzyca typu II, choroba niedokrwienna serca, nadciśnienie tętnicze, zaburzenia gospodarki hormonalnej (testosteron u mężczyzn), ale także niesie za sobą pogorszenie samooceny, a tym samym akceptacji ograniczeń własnego ciała. Celem wykładu jest przedstawienie negatywnego wpływu otyłości na zachowania seksualne. Szczególnym przypadkiem patologicznej otyłości są tzw. feedersi ( „,wypasacze” lub „dokarmiacze”), dla których źródłem fascynacji seksualnej jest tuczenie drugiej osoby, gdyż dla nich jedzenie jest równie zmysłowe jak sam seks. Podsumowując, pozornie „zwykła” nadwaga i otyłość są nieodzownymi elementami naszego życia codziennego i mają znaczny oraz negatywny wpływ na zdrowie fizyczne, psychiczne i funkcje seksualne. 


\title{
Czy szczupła sylwetka może zależeć od stężeń hormonów płciowych w trakcie cyklu menstruacyjnego?
}

\author{
Anna Merklinger-Gruchała ${ }^{1}$, Peter T. Ellison ${ }^{2}$, Inger Thune ${ }^{3}$, Grażyna Jasieńska ${ }^{4}$ \\ ${ }^{1}$ Krakowska Akademia im. Andrzeja Frycza Modrzewskiego, \\ Wydział Zdrowia i Nauk Medycznych, Kraków \\ ${ }^{2}$ Harvard University, Department of Human Evolutionary Biology, Cambridge, UK \\ ${ }^{3}$ Oslo University Hospital, Department of Oncology, Ulleval, Norway \\ ${ }^{4}$ Uniwersytet Jagielloński Collegium Medicum, Wydział Nauk o Zdrowiu, Kraków
}

Zgodnie ze współczesną modą otyłość kobiet jest dużym problemem estetycznym, jednak stanowi ona znacznie większy problem zdrowotny. Przyczyny tej choroby są wieloaspektowe, a jednym z prawdopodobnych czynników wyjaśniających to zjawisko jest poziom apetytu w różnych fazach cyklu menstruacyjnego. Spośród wszystkich faz cyklu menstruacyjnego, najniższe spożycie energii obserwuje się w fazie okołoowulacyjnej. Istotnie większe spożycie kalorii w diecie notowane jest natomiast $\mathrm{w}$ fazie lutealnej w porównaniu z pozostałymi okresami cyklu, tj. dniami okołoowulacyjnymi lub krwawienia miesięcznego oraz fazą folikularną. Większemu spożyciu energii w fazie przedmiesiączkowej, czyli występowaniu tzw. lutealnej hiperfagii, podczas której kobiety spożywają od 90 do $500 \mathrm{kcal} /$ dzień więcej w porównaniu z fazą folikularną, towarzyszą często tzw. zachcianki żywieniowe, czyli zwiększony apetyt na określone (najczęściej słodkie i tłuste) produkty spożywcze. Zmiany w spożyciu energii i składników odżywczych w trakcie cyklu mogą wynikać ze zmian w stężeniach hormonów jajnikowych. Owariektomia stymuluje spożycie pokarmu i przyrost masy ciała. Efekt ten może być odwrócony poprzez podanie estrogenu, który wykazuje działanie hamujące apetyt. W badaniu przeprowadzonym wśród 186 zdrowych ochotniczek w wieku 24-37 lat, które przez okres jednego cyklu menstruacyjnego codziennie pobierały próbki śliny w celu oznaczenia stężeń hormonów płciowych (metodą radioimmunologiczną) oraz siedmiokrotnie wypełniły w tym okresie 24-godzinny kwestionariusz żywieniowy wykazano występowanie zjawiska zwiększonego łaknienia w fazie lutealnej cyklu, wyrażonego zwiększoną dzienną wartością kaloryczną diety. Różnica w spożyciu energii pomiędzy fazą folikularną i lutealną cyklu pozytywnie korelowała z przyrostem masy ciała w okresie badania $(p<0,05)$. Potwierdzona w przeprowadzonym badaniu lutealna hiperfagia może stanowić odpowiedź organizmu na zwiększone wydatki energetyczne w tej fazie cyklu. W fazie przedmiesiączkowej obserwuje się bowiem zwiększenie termogenezy poposiłkowej, tempa metabolizmu w czasie snu, spoczynkowej przemiany materii, a także całkowitych wydatków energetycznych organizmu. Występowanie lutealnej hiperfagii w dłuższym okresie czasu może być odpowiedzialne za nadwagę i otyłość u kobiet w okresie rozrodczym. Zasadne, tak ze zdrowotnego, jak i estetycznego punktu widzenia wydaje się zatem rekomendowanie ograniczania spożycia pokarmu szczególnie w fazie przedmiesiączkowej.

\section{Otyłość, odchudzanie i odmładzanie - co nowego? Relacja ze Światowego Kongresu Medycyny Prewencyjnej, Regeneracyjnej i Przeciwstarzeniowej w Las Vegas w 2011 roku}

\author{
Dorota Malgorzata Wydro
}

\section{Podyplomowa Szkoła Medycyny Estetycznej, Warszawa}

Przedstawione zostaną najnowsze koncepcje patogenezy otyłości - genetyczne, hormonalne i inne ze szczególnym uwzględnieniem zapalenia, jako głównego czynnika leżącego u podłoża większości chorób cywilizacyjnych i zwyrodnieniowych, syndromu X, najnowszych koncepcji leczenia otyłości (dietetycznego, hormonalnego, z użyciem suplementów). Omówiony zostanie również wpływ promieniowania elektromagnetycznego na rozwój chorób zwyrodnieniowych i nowotworowych. 


\section{Flebologia małych żył}

\section{Piotr Sznelewski}

\section{Podyplomowa Szkola Medycyny Estetycznej w Warszawie}

W terapiach mających na celu redukcję drobnych zmian naczyniowych (teleangiektazji, wenulektazji oraz żył siatkowatych) od dawna wykorzystywana jest światłoterapia wysokoenergetyczna, a w szczególności laseroterapia wysokoenergetyczna. W wypadku zmian zbudowanych z siatki bardzo drobnych naczyń o średnicy pojedynczego naczynia poniżej $0,2 \mathrm{~mm}(200 \mu \mathrm{m})$, umiejscowionych płytko pod powierzchnią skóry i zawierających głównie dobrze utlenowaną hemoglobinę (kolor czerwony), które najczęściej lokalizują się na skórze twarzy stosujemy fale o długościach z przedziału 500-600 nm - przedziału określanego jako „drugi pik absorbcji hemoglobiny”. Do tej grupy zaliczamy laser KTP (kryształ potasowo-tytanowo-fosforanowy) emitujący światło o długości fali $532 \mathrm{~nm}$, lasery barwnikowe 577-595 nm lub polichromatyczne źródła intensywnego światła impulsowego (IPL) z zakresu 500-1000 nm. Typowy czas pojedynczego impulsu terapeutycznego dla naczyń tej wielkości powinien wynosić od 5 do $15 \mathrm{~ms}$. Przy kwalifikacji do zabiegów z zastosowaniem laserów wysoko selektywnych $(532 \mathrm{~nm}, 577-595 \mathrm{~nm})$ oraz urządzeń IPL, musimy szczególną uwagę zwracać na ilość melaniny w skórze pacjenta, aby uniknąć powikłań w postaci przebarwień lub odbarwień pozapalnych. Dla zmian złożonych z pojedynczych naczyń rozróżnialnych gołym okiem (średnica w przedziale od 0,2 do $2 \mathrm{~mm}$ ), które często umieszczone są głębiej niż zmiany opisane powyżej, zawierają głównie zredukowaną hemoglobinę (kolor niebiesko-fioletowy) i zwykle występują twarzy lub kończynach dolnych powinniśmy stosować lasery tzw. „trzeciego piku pochłaniania hemoglobiny”, które to pojęcie odnosi się do przedziale 780-1100 nm. „Złotym standardem” w tej grupie urządzeń był do niedawna laser Nd-Yag (neodymowo-yagowy) o długości fali $1064 \mathrm{~nm}$. W ostatnim czasie pojawiły się lasery diodowe 915-940 nm dużej mocy (100-120 W). Krzywe pochłaniania światła dla oksy-Hgb (40\% Hgb) i dezoksy-Hgb pokazują, że światło przedziału 915-940 nm jest silniej absorbowane niź światło $1064 \mathrm{~nm}$ (odpowiednio 2,36 i 5-krotnie), co zapewnia większy komfort zabiegów (mniejsza bolesność) oraz wyższą skuteczność przy mniejszym prawdopodobieństwie powikłań. W zależności od średnicy naczynia (0,2 do $2 \mathrm{~mm})$ czas impulsu laserowego powinien wynosić od 15 do $70 \mathrm{~ms}$.

Opisane wyżej metody terapii, czy to bardzo drobnych naczyń (średnica do 0,2 mm), czy też tych z przedziału 0,2 do $2 \mathrm{~mm}$ opierały się na technikach zabiegu wykorzystującej podawanie światła poprzez skórę (transcutaneous laser treatment) z równoczesnym zabezpieczaniem powierzchni naskórka przez jego chłodzenie zimnym powietrza lub kontaktową chłodzoną końcówką szafirową (typowe rozwiązanie dla urządzeń IPL). Praktyka kliniczna pokazała, że technika przezskórna nie powinna być stosowana w przypadku żył siatkowatych kończyn dolnych, które charakteryzują się średnicą często przekraczającą $3 \mathrm{~mm}$ oraz głębszą lokalizacją. Próby zamykania tego typu naczyń przy użyciu laserowych technik przezskórnych cechują się niską skutecznością oraz dużym ryzykiem powikłań, co wynika z konieczności stosowania bardzo dużych gęstości energii laserowej. Dlatego do chwili obecnej złotym standardem w terapii żył siatkowatych pozostaje skleroterapia. W ostatnim czasie pojawiły się doniesienia o nowej technice laserowej koagulacji żył siatkowatych, która polega na przezskórnym wkłuciu do sterylnego światłowodu o średnicy 200-300 $\mu \mathrm{m}$ i wewnątrznaczyniowej aplikacji impulsu laserowego. Można powiedzieć, że mamy do czynienia z przeniesieniem do skali mikro techniki EVLT (endovenous laser treatment) stosowanej do tej pory w wypadku terapii niewydolności dużych żył układu powierzchownego. W technice tej wykorzystuje się lasery o długościach fali stosowanych w klasycznej EVLT dużych naczyń: 808 nm, 940 nm, 980 nm oraz 1064 nm, natomiast stosowane wartości mocy światła laserowego są dużo niższe i wynoszą od 1 do $3 \mathrm{~W}$. Techniki wykorzystujące lasery i urządzenia IPL stały się ważnym elementem współczesnej flebologii. Należy jednak pamiętać o tym, że każda z nich może okazać się nieskuteczna lub wręcz szkodliwa w wypadku nieprawidłowej kwalifikacji lub złego wykonania zabiegu. Najnowocześniejsze rozwiązania technologiczne nie zwalniają nas od myślenia i staranności na każdym etapie diagnostyki i terapii. 


\title{
Flebologia estetyczna dużych żył
}

\author{
Zbigniew Rybak
}

Zakład Chirurgii Eksperymentalnej i Badania Biomateriałów Akademii Medycznej we Wrocławiu

Żylaki kończyn dolnych stanowią poważny problem estetyczny. Zwłaszcza dotyczy on kobiet. Znaczne poszerzenia żylne są spowodowane zaburzeniami syntezy elementów pozakomórkowych oraz przebudową ściany naczynia co skutkuje niewydolnością głównych pni żył powierzchownych ( żyły odpiszczelowej i /lub odstrzałkowej ), poszerzeniem i niewydolnością żył przeszywających uda i/lub goleni, niedrożnością żył głębokich ( żylaki są w tej sytuacji krążeniem zastępczym dla niedrożnych żył głębokich ). Częstość występowania żylaków w Polsce szacuje się na około 34\%.

\section{Diagnostyka}

Współcześnie obligatoryjną metodą diagnostyczną rekomendowaną przez Polskie Towarzystwo Flebologiczne jest duplex/Doppler. Badanie to pozwala na wizualizację anatomicznych struktur naczyniowych, uwidocznienie kierunku przepływu krwi oraz pomiar i zapis stwierdzanych patologii. W przypadkach wątpliwych zalecana jest flebografia oraz bezpośredni pomiar ciśnienia żylnego.

\section{Leczenie}

W ostatnim okresie wzrosło znaczenie stosowania technik wewnątrznaczyniowych w leczeniu choroby żylnej. Badania porównawcze metod operacyjnych i wewnątrznaczyniowych wskazują, że skuteczność obu metod jest porównywalna, jednak takie zalety jak brak konieczności znieczulenia ogólnego lub regionalnego, możliwość przeprowadzenia leczenia w warunkach ambulatoryjnych, skrócony czas powrotu do pełnej aktywności życiowej, krótszy okres dolegliwości bólowych po zabiegu przemawiają za wyborem metod wewnątrznaczyniowych. Dodatkową zaletą leczenia endowaskularnego jest możliwość zastosowania chemicznej sklerotyzcaji pozostałych po leczeniu zasadniczym żylaków powstałych wzdłuż niewydolnych bocznic głównych pni.

\section{Profilaktyka}

W celu utrwalenia efektu leczniczego bardzo istotna jest profilaktyka zapobiegająca nawrotom choroby żylnej. Główną składową skutecznej profilaktyki są wyroby o stopniowanej kompresji, wywierające stopniowany ucisk na całej długości kończyny - największy w okolicy stopy i stawu skokowego, a zmniejszający się w kierunku pachwiny. Zewnętrzny ucisk przeciwdziała siłom rozpierającym naczynia żylne od wewnątrz. Drugą bardzo ważną składową profilaktyki jest farmakoterapia. Wśród leków najbardziej skutecznych w przeciwdziałaniu chorobie żylnej jest zmikronizowana diosmina .

\section{Stan hormonalny ustroju w wieku dojrzałym - implikacje fizyczne i psychiczne}

\section{Włodzimierz Bednorz}

\section{Klinika Endokrynologii, Diabetologii i Leczenia Izotopami AM we Wroclawiu}

Starzenie się każdego z nas jest niestety procesem nieuchronnym. Dotyczy ono wszystkich narządów: skory, kości, ale także gruczołów dokrewnych. Znane są typowe objawy schorzeń wynikających z niedoborów hormonalnych, w ostatnich latach zaczęto zwracać także uwagę na subkliniczne postaci niedoczynności tarczycy, nadnerczy i niedobory testosteronu u mężczyzn i estrogenów u kobiet. Kluczowe jest rozpoznanie wczesnych objawów zespołu menopauzy, istotne wydaje się także dobranie odpowiednich preparatów (indywidualizacja leczenia). Już samo rozpoznanie andropauzy budzi kontrowersje. W wykładzie zostaną przedstawione propozycje terapeutyczne niedoboru testosteronu. W ostatnich latach odkryto istotną rolę wi- 
taminy D w różnych schorzeniach, dlatego zostaną omówione nowe poglądy na to zagadnienie. Krytycznej i analitycznej ocenie zostanie poddany problem ,hormonów młodości”. Poruszone zostaną także problemy medyczne i etyczne niektórych kontrowersyjnych terapii.

\title{
Tkanka skórna a aktywność fizyczna - granice promocji zdrowia
}

\author{
Jerzy Jaśkiewicz¹, Dorota Lizak ${ }^{1}$, Anna Gawędzka² \\ ${ }^{1}$ Krakowska Akademia im. Andrzeja Frycza Modrzewskiego, Kraków \\ ${ }^{2}$ Akademia Wychowania Fizycznego im. Bronisława Czecha, Kraków
}

Wysiłek fizyczny to reakcja całego organizmu skutkująca przyspieszeniem przemian metabolicznych. Szczególnego rodzaju zmiany w odpowiedzi na wysiłek zachodzą w tkance skórnej. Jest to bowiem jedyna tkanka mająca bezpośredni kontakt ze środowiskiem zewnętrznym. Stąd też w tkance skórnej następują reakcje adaptacyjne wywołane bodźcami środowiska wewnętrznego i zewnętrznego. W wysiłku aktywniej zachodzi proces termoregulacji, połączony między innymi z wydzielaniem potu. Wydzielina ta wywołuje zmiany metaboliczne w żywych komórkach naskórka. Bodźce zewnętrzne, takie jak temperatura, promienie UV czy różnego rodzaju ksenobiotyki, pobudzają reakcje obronne tak w naskórku jak i w skórze właściwej. Tkanka skórna w warunkach powtarzających się zmian charakterystycznych dla uprawianych określonych dyscyplin sportu ulega różnym rodzajom reakcji obronnych. Obserwuje się zmiany aktywności fibroblastów, przemian białek kolagenowych i metaloproteinaz, natężenia podziałów komórek warstwy podstawnej i wydzielania barwników. Równocześnie wzrasta aktywność mikrokrążenia odżywczego i zespoleń tętniczo-żylnych tkanki skórnej. Warunkiem zachowania zdrowia jest utrzymywanie należytej sprawności fizycznej. Stan taki osiąga się poprzez celowy i właściwy dla płci i wieku wysiłek fizyczny. Dla utrzymania zdolności adaptacyjnych organizmu konieczne jest regularne uprawianie wybranych dyscyplin sportu. Zawsze jednak należy pamiętać o wydolności organizmu, a stan ten determinuje wiek i tryb życia.

\section{Implantacja w odcinku estetycznym - wyzwanie terapeutyczne czy codzienność?}

\section{Marzena Dominiak}

\section{Katedra i Zakład Chirurgii Stomatologicznej AM we Wrocławiu}

Implantacja jest zabiegiem umożliwiającym uzupełnienie braków zębowych powstałych w wyniku ich utraty z przyczyn fizjologicznych lub patologicznych. Jednakże celem skutecznej implantacji obecnie nie jest tylko uzupełnienie braków zębowych, zwłaszcza w odcinku przednim, ale wykonanie jej w sposób maksymalnie estetyczny. O ile jest to możliwe w przypadku zachowanych wszystkich ścian kostnych zębodołu lub wyrostka zębodołowego, to staje się to niemożliwe w przypadku redukcji podłoża kostnego. Utrata wyrostka zębodołowego jest problemem uniemożliwiającym estetyczna rehabilitację protetyczną, ale również stabilizację i retencję leczenia implantoprotetycznego. Deficyt w obrębie wyrostka zębodołowego może wynikać z ubytków w wymiarze pionowym, poziomym, a także ich kombinacji. W pracy przedstawiono obecne możliwości rekonstrukcji ubytków kostnych wyrostka z podziałem ze względu na wielkość ubytku oraz współwystępującą utratę tkanek miękkich. Skuteczna odbudowa tkanek twardych i miękkich warunkuje bowiem możliwość estetycznej i stabilnej w perspektywie długofalowej rehabilitacji protetycznej z wykorzystaniem implantów. 


\title{
Metaloproteinazy jako nowy wskaźnik diagnostyczny nowotworów skóry
}

\author{
Anna Goździalska ${ }^{1,2}$, Jagoda Drąg ${ }^{1}$, Anna Gawędzka ${ }^{1,4}$, Katarzyna Kowalska ${ }^{1}$, Paweł Brzewski ${ }^{3}$, Anna \\ Wojas-Pelc $^{3}$, Jerzy Jaśkiewicz ${ }^{1}$ \\ ${ }^{1}$ Wydzial Zdrowia i Nauk Medycznych, Krakowska Akademia im. Andrzeja Frycza Modrzewskiego, \\ Kraków \\ ${ }^{2}$ Zakład Analityki Biochemicznej, Wydział Farmaceutyczny Collegium Medicum UJ, Kraków \\ ${ }^{3}$ Katedra i Klinika Dermatologii Collegium Medicum UJ, Kraków \\ ${ }^{4}$ Zakład Farmakologii i Biofizyki AWF, Kraków
}

Metaloproteinazy macierzy zewnątrzkomórkowej (matrix metalloproteinases, MMPs) to grupa metalozależnych endopeptydaz katalizujących proteolizę składników macierzy zewnątrzkomórkowej (extracellular matrix, ECM). Prawidłowa aktywność MMPs niezbędna jest dla zachowania właściwej struktury tkanki łącznej. Aby równowaga pomiędzy syntezą i proteolizą składników ECM została zachowana, ekspresja, lokalizacja oraz aktywność tych enzymów jest ściśle regulowana. Synteza oraz aktywność metaloproteinaz podlega regulacji na wielu poziomach celem zabezpieczenia środowiska zewnątrzkomórkowego przed niekontrolowaną degradacją jego elementów. Metaloproteinazy odgrywają rolę w wielu fizjologicznych i patologicznych procesach zachodzących w żywym organizmie. MMPs degradują składniki ECM, w tym białka kolagenowe, proteoglikany i lamininy, przez co umożliwiają migrację komórek, a także regulują strukturę macierzy zewnątrzkomórkowej oraz utrzymanie prawidłowych funkcji komórek tkanki łącznej.

Zaburzenie równowagi pomiędzy metaloproteinazami a czynnikami je hamującymi leży u podstaw wielu schorzeń. Należy podkreślić udział tych enzymów w inwazji licznych nowotworów, czego dowodem jest wzrost aktywności metaloproteinaz m.in. w raku piersi, macicy, prostaty, pęcherza moczowego, przełyku, jelita grubego, czy skóry. Niejednorodność komórek tworzących ogniska przerzutów nowotworowych, zróżnicowane umiejscowienie i wielkość zmian nowotworowych niewykrywalna za pomocą dostępnych metod diagnostyki obrazowej to cechy rozsianych zmian nowotworowych przyczyniające się do wysokiej umieralności wśród pacjentów onkologicznych. Rak skóry jest jednym z częściej diagnozowanych nowotworów. Wśród rozpoznanych jednostek chorobowych najliczniej występują nieczerniakowe raki skóry takie jak płaskonabłonkowy rak skóry (squamous cell carcinoma, SCC) czy rak podstawnokomórkowy (basal cell carcinoma. BCC). Promieniowanie słoneczne jest najważniejszym czynnikiem środowiskowym promującym rozwój nowotworów skóry, w wyniku nagromadzenia w genomie zmian mutacyjnych. W związku z wzrastającą liczbą zachorowań na NMSC (non-melanoma skin cancer) prowadzone są liczne badania celem poznania patogenezy tych nowotworów oraz opracowania skutecznych metod terapeutycznych. Istotne zatem jest poszukiwanie czynników promujących powstawanie przerzutów. Takimi markerami inwazyjności mającymi udział w procesie metastazy są metaloproteinazy. Dowiedzione różnice w zakresie aktywności MMPs pomiędzy tkankami zmienionymi nowotworowo a tkankami prawidłowymi stają się punktem wyjścia do wyboru testów dla enzymów proteolitycznych przebiegających równolegle z badaniami histopatologicznymi. Możliwe zatem będzie stworzenie systemu klasyfikacji zmian histopatologicznych obejmujący również zmiany molekularne dotyczące ekspresji mRNA, białek i aktywności dla MMPs. Poprawi to znacząco jakość odróżnienia tkanki guza od tkanki prawidłowej, co pozwoli zmniejszyć ilość wznów nowotworowych. 


\title{
Bezpieczeństwo współczesnych kosmetyków
}

\author{
Magdalena Jurzak ${ }^{1,2}$, Anna Goździalska², Jerzy Jaśkiewicz² \\ ${ }^{1}$ Śląski Uniwersytet Medyczny w Katowicach, Wydział Farmaceutyczny z Oddziałem Medycyny \\ Laboratoryjnej, Katowice \\ ${ }^{2}$ Krakowska Akademia im. A. Frycza Modrzewskiego, Wydział Zdrowia i Nauk Medycznych, \\ Kraków
}

\begin{abstract}
Skóra składająca się z wielu warstw i wielu typów komórek spełnia ważne dla organizmu funkcje. Jest narządem najbardziej eksponowanym i narażonym na stresy środowiskowe, szczególnie promieniowanie ultrafioletowe (UV). Promieniowanie UV powoduje nadprodukcję wolnych rodników odpowiedzialnych za stres oksydacyjny, starzenie skóry (fotostarzenie), stany zapalne i transformację komórek prawidłowych w komórki nowotworowe. Rosnące zapotrzebowanie rynku na produkty kosmetyczne wyznacza kierunek rozwoju bardzo dynamicznej dziedziny, jaką jest kosmetologia. Współczesnym trendem kosmetologii jest nie tylko poszukiwanie nowych składników aktywnych kosmetyków o wielokierunkowym działaniu - antyutleniającym, nawilżającym, łagodzącym, regenerującym, redukującym zmarszczki, ale także poszukiwanie substancji zarówno naturalnych, jak i syntetycznych zapobiegających, hamujących lub odwracających transformację nowotworową komórek, czyli substancji o potencjalnych właściwościach chemoprewencyjnych. Wprowadzanie na rynek nowych składników czynnych kosmetyków, często tworzonych z zastosowaniem zaawansowanych technologii, niesie ryzyko wywoływania przez nie różnego rodzaju działań niepożądanych m.in. działania drażniącego skórę i oczy, działania uczulającego skórę, fototoksyczności oraz działania kancerogennego. Badania składników aktywnych zawartych w kosmetykach wymagają potwierdzenia nie tylko skuteczności działania danej substancji czynnej, możliwości różnokierunkowego zastosowania ale również określenia natychmiastowych i długotrwałych skutków oraz działań niepożądanych.
\end{abstract}

Wstępne etapy opracowywania rzeczywiście skutecznych produktów kosmetycznych, często wykazujących również działanie chemoprewencyjne, obejmują przede wszystkim stosowanie ścisłego programu wykrywania substancji metodami biologii komórkowej i molekularnej w celu zidentyfikowania substancji czynnych mających pożądane działanie biologiczne, ale także zastosowanie programu badań dla określenia, że zidentyfikowana substancja czynna nie powoduje działań niepożądanych. Hodowle komórkowe, szczególnie przestrzenne (3D, three dimensional), stwarzają nie tylko możliwość poszukiwania i testowania nowych substancji aktywnych jako składników czynnych kosmetyków, ale również zapewniają powtarzalność uzyskanych wyników i często stanowią metody alternatywne do testów prowadzonych na zwierzętach. Prowadzenie wielokierunkowych badań oceniających zarówno skuteczność, jak i ocenę efektów niepożądanych z zastosowaniem nowoczesnych technologii: analizy ekspresji genów (transkryptomiki), genomiki, proteomiki czy metabolomiki może dać solidne podstawy naukowe nie tylko dla poszukiwania nowych składników czynnych kosmetyków, ale może przyczynić się do zrozumienia mechanizmów wielu chorób skóry o niejasnej dotychczas etiopatogenezie (np. łuszczyca), a także pozwolić na zastosowanie szeroko rozumianej chemoprewencji.

\section{Synteza tkanki skórnej - techniki molekularne w kosmetologii}

\author{
Jagoda Drąg ${ }^{1}$, Anna Goździalska ${ }^{1,2}$, Anna Gawędzka ${ }^{1,3}$, Magdalena Jurzak ${ }^{4}$, Jerzy Jaśkiewicz ${ }^{1}$ \\ ${ }^{1}$ Wydział Zdrowia i Nauk Medycznych, Krakowska Akademia im. Andrzeja Frycza Modrzewskiego, \\ Kraków \\ ${ }^{2}$ Zakład Analityki Biochemicznej, Wydział Farmaceutyczny Collegium Medicum UJ, Kraków \\ ${ }^{3}$ Zakład Farmakologii i Biofizyki AWF, Kraków \\ ${ }^{4}$ Śląski Uniwersytet Medyczny w Katowicach, Wydział Farmaceutyczny z Oddziałem Medycyny \\ Laboratoryjnej, Katowice
}

Skóra jest stale zmieniającym się organem, który zawiera wiele wyspecjalizowanych komórek i struktur. 
Skóra chroni przed zakażeniem drobnoustrojami, przed czynnikami mechanicznymi, termicznymi, chemicznymi i promieniowaniem świetlnym oraz zapewnia homeostazę. Zbiera informacje sensoryczne z otoczenia, odgrywa aktywną rolę w układzie odpornościowym oraz bierze udział w magazynowaniu i przemianie materii. Zrozumienie złożoności funkcji skóry rozpoczyna się od pojęcia struktury trzech warstw skóry - naskórka, skóry właściwej i tkanki podskórnej. Naskórek stanowi tkankę ulegającą ciągłej odnowie i regeneracji, zbudowany jest głównie z keratynocytów, będących na różnym etapie różnicowania. Keratynocyty odgrywają zasadniczą rolę w utrzymaniu bariery naskórkowej, a także w procesach immunologicznych skóry. W połączeniu z melanocytami (komórkami barwnikowymi) uczestniczą w procesach syntezy barwnika w skórze. Utrzymanie odpowiedniej równowagi i odnowy naskórka możliwe jest dzięki właściwościom regeneracyjnym komórek macierzystych, prekursorów keratynocytów. W skórze właściwej licznie występują fibroblasty odpowiedzialne za syntezę kolagenu i elastyny zapewniających skórze elastyczność. Główną funkcją fibroblastów jest utrzymanie strukturalnej integralności tkanek łącznych poprzez wydzielanie prekursorów macierzy zewnątrzkomórkowej, ponadto zawierają one błonowe białka uczestniczące w procesach adhezji, integrujące komórki i składniki substancji międzykomórkowej.

Komórki macierzyste naskórka biorą również udział w procesie gojenia się ran, a także w patogenezie nowotworów skóry. Wyhodowane ludzkie keratynocyty i komórki macierzyste naskórka mogą być przeszczepiane w postaci opatrunków w leczeniu oparzeń, chronicznych owrzodzeń oraz różnych chorób skóry. Komórki macierzyste naskórka stanowią cel terapii genowej oraz materiał do testowania nowych leków. Fibroblasty są materiałem wykorzystywanym do przeszczepów w leczeniu oparzeń, blizn oraz trudno gojących się ran. Funkcje keratynocytów i fibroblastów są szeroko wykorzystywane w hodowlach komórek i tkanek. Uzyskane in vitro komórki stosowane są w transplantologii. W kosmetologii, wykorzystuje się hodowle jednego typu komórek (keratynocytów lub fibroblastów), kokultury, a także tzw. modele skóry np. model naskórka czy model skóry pełnej. Modele skóry znalazły zastosowanie do badania wpływu substancji kosmetycznych na ekspresję genów, syntezę białek i badanie aktywności wielu enzymów. Hodowle komórkowe pozwalają na obserwacje wpływu różnych czynników na zachowanie się komórek skóry zdrowej oraz w warunkach patologicznych, takich jak bielactwo, czerniak lub łuszczyca.

\section{Starzenie się skóry - fizjologia czy patologia?}

\section{Radosław Śpiewak}

\section{Zakład Dermatologii Doświadczalnej i Kosmetologii, Wydział Farmaceutyczny, Uniwersytet Jagielloński Collegium Medicum, Kraków}

Proces starzenia postrzegany jest przez wielu ludzi jako „choroba”. Z punktu widzenia jednostki można zrozumieć taką postawę, jednak ewolucjoniści zwracają uwagę, że starzenie może być rozwiązaniem korzystnym dla gatunków. Z wyjątkiem prymitywnych jamochłonów, procesy starzenia somatycznego stwierdza się u wszystkich zwierząt. Warto sobie uświadomić, że starzenie nie jest tylko prostym procesem ,zużywania się" komponentów organizmu, lecz obejmuje szereg aktywnych, wypracowanych w toku ewolucji mechanizmów, a struktura komórek i narządów determinuje ich „czas życia”. Procesy starzenia zachodzące w skórze wzbudzają szczególne zainteresowanie, ponieważ wygląd skóry dostarcza otoczeniu łatwo zauważalnych informacji między innymi o wieku - istotnym czynniku determinującym atrakcyjność jednostki.

Skóra jest największym narządem organizmu ludzkiego, stanowiącym 15\% całkowitej masy ciała. Dzięki wysokiej złożoności, ten wielofunkcyjny narząd chroni środowisko wewnętrzne przed szerokim wachlarzem szkodliwych wpływów środowiska - od promieniowania słonecznego aż po mikroorganizmy, od urazów mechanicznych aż po toksyny. Skóra odgrywa ponadto istotną rolę w gospodarce węglowodanowej, tłuszczowej i mineralnej, termoregulacji, regulacji hormonalnej, a pod względem nagromadzenia komórek odporności immunologicznej zajmuje drugie miejsce wśród wszystkich układów ciała. Integralność oraz sprawność funkcjonalną skóra zawdzięcza nieustającym procesom regeneracyjnym, których efektywność spada w miarę zużycia. Z wiekiem cykl naskórkowy (czas pełnej regeneracji keratynocytów) ulega spowolnieniu, w warstwie rogowej spada zawartość lipidów (suchość skóry, zaburzenia bariery skórnej), obniża się liczba aktywnych melanocytów (słabsza ochrona przed UV) i komórek Langerhansa (osłabienie odporności immunologicznej), zmniejsza się liczba gruczołów potowych, w tkance podskórnej stopniowo zanikają naczynia 
krwionośne. Z wiekiem zmienia się stosunek poszczególnych typów kolagenu w tkance podskórnej, wytwarzają się wiązania krzyżowe włókien kolagenowych i elastynowych. Potencjał regeneracyjny poszczególnych ludzi jest zróżnicowany i w znacznym stopniu od nich niezależny. Jednak każda jednostka ma możliwość racjonalnego gospodarowania zasobami regeneracyjnymi otrzymanymi w darze od natury, co otwiera pole dla rzetelnej i opartej na dowodach naukowych promocji zdrowia. Zrozumienie mechanizmów starzenia jako integralnej części cyklu życiowego i wdrożenie racjonalnej profilaktyki do codziennego życia może dać szansę spowolnienia tych procesów, co wydaje się znacznie bardziej realne od marketingowych obietnic „zatrzymania”, czy wręcz „cofnięcia czasu”.

\title{
Komórki macierzyste w medycynie estetycznej i anti-aging
}

\author{
Pawel Surowiak ${ }^{1,2,3}$ \\ ${ }^{1}$ Katedra Histologii i Embriologii, Akademia Medyczna we Wroclawiu \\ ${ }^{2}$ Polskie Towarzystwo Medycyny Estetycznej i Anti-Aging, PTL w Warszawie \\ ${ }^{3}$ Instytut DermaMed we Wroclawiu
}

Komórki macierzyste są w ostatnich latach poddawane licznym badaniom pod kątem zastosowania ich w różnych gałęziach medycyny. Badania te dotyczą głównie aspektów regeneracji tkanek uszkodzonych w wyniku urazu lub schorzenia, bądź zdegenerowanych w wyniku procesu starzenia. Medycyna estetyczna jest jedną z nielicznych dziedzin, wykorzystujących w praktyce autologiczne komórki macierzyste w celu uzyskania efektu terapeutycznego. Pierwsze próby użycia autologicznych tkanek sięgają XIX wieku, kiedy to dr Franz Neuber w roku 1893 dokonał zabiegu transplantacji fragmentu tkanki tłuszczowej z ramienia na twarz w miejsce zniekształcone gruźliczym zapaleniem kości. Jednak, prawdziwym postępem było wprowadzenie na rynek metody przeszczepu autologicznych fibroblastów. Zabieg ten polega na wyhodowaniu w warunkach in vitro fibroblastów z małego wycinka skóry pacjenta, a następnie wstrzyknięciu w jego skórę namnożonych komórek. Opublikowane liczne badania kliniczne wykazują wysoką skuteczność tej metody w korekcji różnego rodzaju objawów starzenia się skóry oraz takich zmian jak blizny oraz wieloletnią trwałość efektów. W ostatnich latach ukazały się liczne prace opisujące bardzo wysoki potencjał zawartych w skórze różnych populacji komórek macierzystych. Szczególnym zainteresowaniem cieszą się mezenchymalne komórki macierzyste (MSC), które maja dużo wyższy potencjał regeneracyjny od fibroblastów. Podejmowane są próby zastosowania pochodzących ze skóry MSC w regeneracji innych narządów i tkanek. Trwają również prace nad odróżnicowaniem komórek macierzystych skóry do komórek macierzystych totipotencjalnych. Niezależnie od typu komórek wykorzystywanych w medycynie regeneracyjnej oraz od kierunku rozwoju tej dziedziny wiedzy, celowym wydaje się propagowanie idei biobankingu. Biorąc pod uwagę fakt starzenia się komórek, najwyższą skuteczność będą wykazywały zabiegi przeprowadzane z użyciem młodych komórek danego pacjenta. 